\title{
Ukraine's window to the West: The role of international railway connection in Transcarpathia (Zakarpattia)
}

\author{
IvAN G. SAVCHUK ${ }^{1}$
}

\begin{abstract}
In this paper the role of railway network of Transcarpathia (Zakarpattia) in the international transport connections of Ukraine is investigated. The geopolitical importance and favourable transit location of this region within Ukraine along the international boundaries with Hungary, Romania and Slovakia, is well-known. The paper first focuses on the role of natural, political and transport factors in the development of railway network in the region from a historical perspective. Then the importance of railway network in Transcarpathia for the development of international freight traffic in the USSR is highlighted. The role of geopolitical interests in the past and present is demonstrated. The analytical part of the paper focuses on the latest changes in international freight traffic in the region in the period of 2008-2011, and major obstacles in its development are also discussed. The peculiarities of international freight traffic passing through border freight stations of the given region and the contiguous countries are assessed.
\end{abstract}

Keywords: Ukraine, Transcarpathia, transport geography, railway network, geopolitics, international freight traffic

\section{Introduction}

Even though railway networks plays a strategic role in the international communication of post-Soviet states this aspect has not been adequately investigated for Ukraine since its independence in 1991. Ukraine is one of the leading countries in Europe regarding the development of transport infrastructure and the volume of commercial passenger and freight traffic. It ranks $4^{\text {th }}$ within Europe regarding the length of publicly operated railway lines, $6^{\text {th }}$ in term of the number of locomotives and $2^{\text {nd }}$ with regards the number of railway carriages. The significance of Ukraine in the European railway transport is well reflected

\footnotetext{
${ }^{1}$ Institute of Geography of the National Academy of Sciences of Ukraine, vul. Volodymyrska, 44, 01034, Kyiv, Ukraine. E-mail: ivansavchuk@yahoo.com
} 
by the fact that 6 out of the 13 railway corridors of the Organization for Cooperation between Railways (OSJD), and 3 out of the 10 European railway corridors (III, V and IX) pass through the territory of Ukraine (Kocsis, K. et al. 2008; Soglasovannaya... 2002, 41-43; Natsionalnyy... 2007, p. 39). Two of them pass through Transcarpathia (Zakarpattia Oblast) reflecting their importance for international relations.

Transcarpathia as 'window to the West' plays a very important role in the international traffic of Ukraine. The region has a number of distinct geographical features, which, in our opinion, have direct impact on its relevance and opportunities in the international railway transport. These are

- the relative geographical (and traffic) isolation of Transcarpathia from the rest of the country, determined by the range of Carpathians (natural factor);

- the geopolitical location of Transcarpathia in the extreme west of Ukraine neighbouring four independent states (i.e. more than any other region of the country) (political factor),

- the transit position of the local railway network, leading to its specific spatial configuration (transport factor).

In this study we will consider the role of each of these factors in the development of the international freight traffic in Transcarpathia. Basis of this research is provided by our earlier methodological works (SAVCHUK, I.G. 2010a,b,c, 2011, 2012a,b). In addition, we collected and analysed data obtained from the Statistics of the International Union of Railways, the State Statistics Service of Ukraine and Ukrzaliznytsya (Alenichev, S.P. 2004; Budivnytsvo... 2012). Secondary sources were also considered (KIRPA, G.M. 2004; Ohlyad... 2001 etc.). With the use of statistical approaches the main tendencies in railway communications in Transcarpathia were determined.

\section{The role of different factors in the development of railway network in Transcarpathia (Zakarpattia)}

\section{Natural factors}

The ranges of Carpathians played an important role in the development of transport network, including railway lines, of present-day Transcarpathia. As Table 1 demonstrates only three out of the ten existing passes are used for railway communication today. The Transcarpathian railway lines were constructed by the Austro-Hungarian Monarchy through Beskydskyi (Budapest-Chop-Lviv, 1886), Voronenkivskyi (Ivano-Frankivs'k-Deliatin-Berlebash, 1895) and Uzhotskyi (Budapest-Uzhhorod-Lviv, 1872) passes. Their construction was also prompted by military strategic considerations. 
The relevance of military strategic considerations for laying down the railways through the Carpathian Mountains is well reflected by the comparison of two adjacent sections of the former administrative border between Cisleithanien and Transleithanien (at present the administrative border between Transcarpathia as well as Ivano-Frankivs'k, Lviv and Chernivtsi regions of Ukraine in the Ukrainian Carpathians and the Polish-Slovak state border in the Western Carpathians). These two sections of Carpathians have very similar geographical characteristics. However, while the $280 \mathrm{~km}$ long Ukrainian Carpathians is crossed by three railway lines, the $541 \mathrm{~km}$ long Western Carpathians is crossed by only one minor railway line between Prešov (Slovakia) and Nowy Sącz (Poland). In the Austro-Hungarian epoch the only binary railway in the Carpathians was located here - the First HungarianGalician railway (from 1896 to 1920). Przemyśl was connected with Budapest through the tunnel under Lupkov pass after 1874. However, the tunnel was destroyed in 1944, and until 1999 it was not used in the regular train services between Slovakia and Poland.

The Beskydskyi Pass is the most intensively used pass today, through which the main Ukrainian binary electrified railway of international significance Moscow-Kyiv-L'viv-Uzhhorod/Chop passes. It is continued in the Hungarian and Slovak railway network. The high ranges of Carpathians make high speed communication impossible (Photo 1).

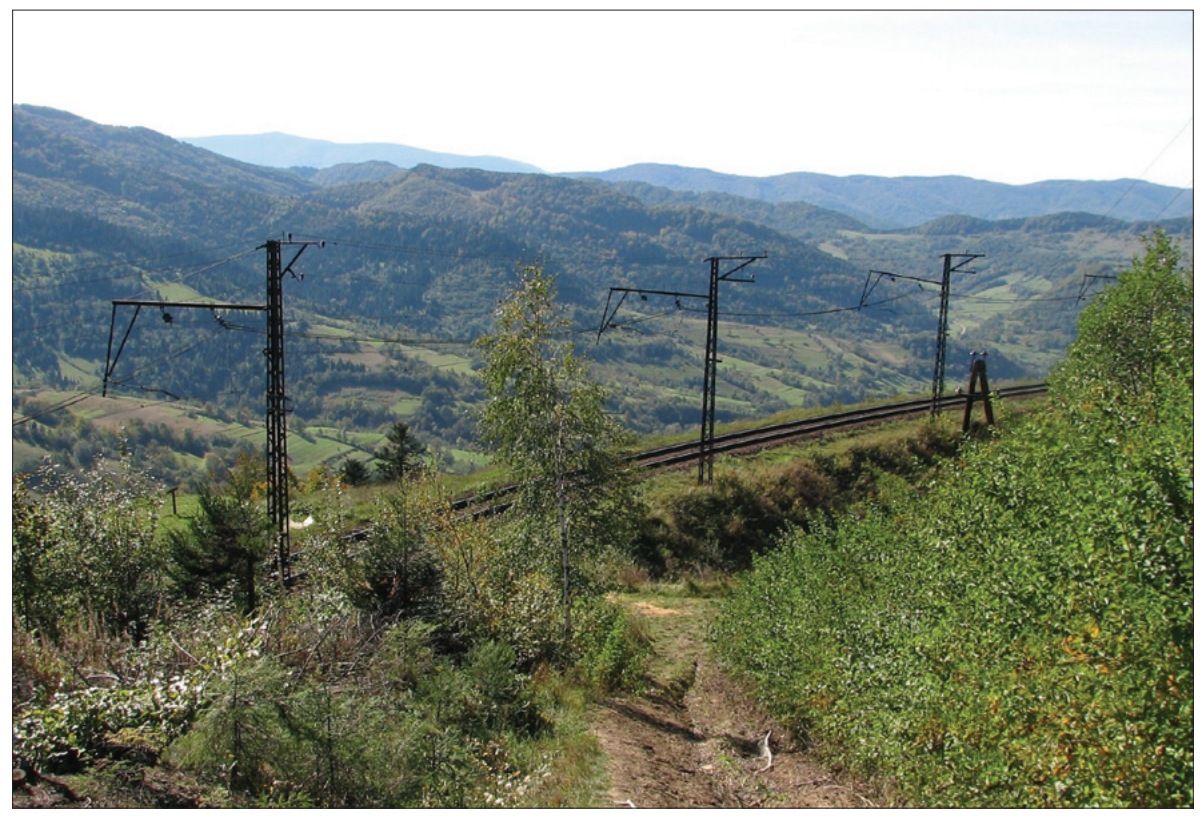

Photo 1. Railway line near Uzhok station (Velykobereznianskyi Raion) 


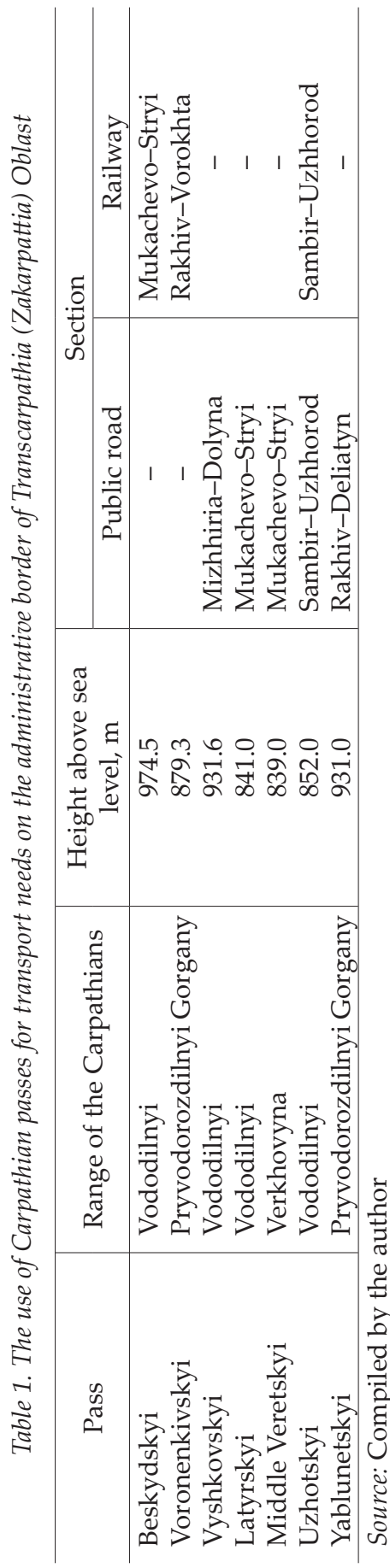

It should also be noted that in the mountainous part of Transcarpathia most sections of the railway lines run through the valleys of the main rivers including the Borzhava, Latorytsia, Uzh and Tisza (Figure 1). This is primarily due to engineering and geomorphologic conditions. The railway lines run very often parallel to main roads at several sites (Table 1).

The main natural challenges of the railway traffic in the lower part of Transcarpathia is the threat of floods at several railway network sections and erosion due to catastrophic floods, and destruction of bridges. For example, during the spring floods of 1998 and 20013.1 and $9.15 \mathrm{~km}$ of railways were damaged and 2.4 and $1.4 \mathrm{~km}$ were destroyed (Ohlyad... 2001). In 2008 the traffic was temporarily closed on the section of Teresva-Solotvyno due to substantial destruction of the roadbed by heavy rains. Considering the effects of natural factors in the railway network of Transcarpathia, certain isolation from the main railway network in Ukraine can be pointed out, which has a direct impact on international traffic.

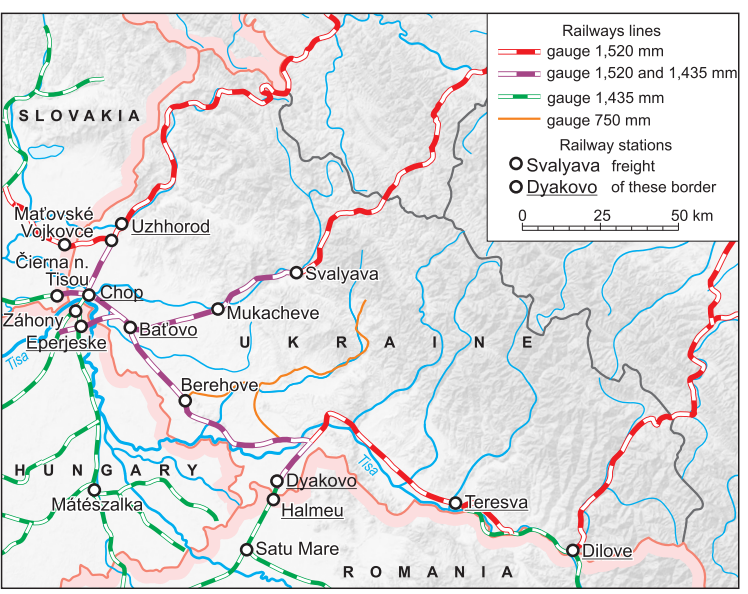

Fig. 1. The existing railway network of Transcarpathia 


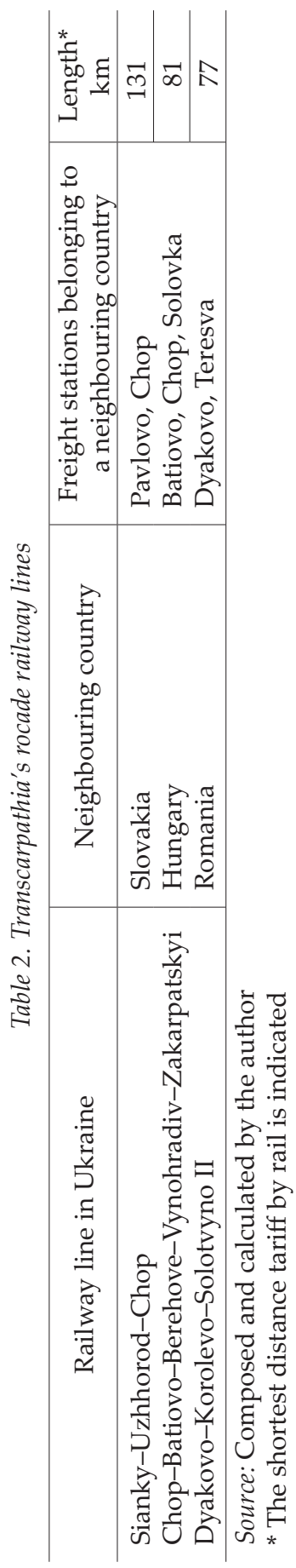

\section{Political factors}

Among all the regions of Ukraine the geopolitical position of Transcarpathia is quite unique. It is bordered by four independent states which, undoubtedly, is a significant precondition for the development of external connections, especially in the service sector. The region is the only one in Ukraine that has borders with Hungary and Slovakia. Both countries Hungary before 1918, and Czechoslovakia in the interwar period controlled this part of Ukraine and used Transcarpathia for its own political and economic goals, i.e., for the implementation of their foreign political and economic strategies of confrontation with other states.

Except for the border with Slovakia the present-day border of Transcarpathia was established in accordance with $\S 53$ of Saint-Germain Peace Treaty (1919) and $\S 48$ of the Treaty of Trianon (1920), according to which this region became part of the Czechoslovak Republic. Part of the railway line Košice-Chop-Khust-Rakhiv goes through its territory - it unites Trascarpathia into the single whole through the Chop-Batiovo-Vynohradiv-Zakarpatskyi (Table 2) line and connects it with Slovakia and Romania.

The problem of the Velykyi Bychkiv-Dilove section at the Korolevo-Berlebash railway derives from the geopolitical legacy of the Versailles Peace Treaty. The section is cut by the modern state border between Romania and Ukraine into two separate parts. Thus, the Ivano-Frankivs'k-Deliatyn-Berlebash (1895) railway is isolated from the railway network of Transcarpathia.

The adjoining part of Teresva/Câmpulung la Tisa-Dilove/Valea Vișeului belongs to Romania. At the time this railway was constructed it was located completely in Transleithanien and connected the towns of Satu Mare and Baia Mare.

It starts from the city of Sighetu Marmației and runs further into the territory of Romania, which is crucial for the railway connection of the town with the rest of the Romanian railway network. Due to 
military geographic reasons a section of the Velykhyi Bychkiv-Dilove railway was incorporated into Romania, not Czechoslovakia².

According to the Agreement between the Union of Soviet Socialist Republics and the Czechoslovak Republic on the Transcarpathian Ukraine (06.29.1945) this region was attached to the Ukrainian SSR with its boundaries established before 29.09.1938, and the line of the state border between Czechoslovakia and the Soviet Union was acknowledged according to the administrative border between Slovakia and Subcarpathian Rus as of 08.10.1938, with the concession of the town of Chop and the county (about $250 \mathrm{~km}^{2}$ ) to the USSR. After the adjustment of the state border between the two states the village of Lekarovce was passed to the Slovak Republic (04.02.1946).

As a result of the territorial expansion of the USSR Transcarpathia received direct state border connection with all the countries of Central Europe at once. From Transcarpathia the Soviet leadership could directly control the neighbouring countries, and their trade with the USSR. The Transcarpathian passes and the Chop railway junction which became part of the Soviet Union thus gained high geopolitical importance.

As a consequence of border changes the once peripheral but integral railway network became heavily fragmented and their operation became strongly dependant on the transit traffic among neighbouring countries.

The most significant transformation in the development of Transcarpathia's railway network took place after its inclusion in the Soviet Union. One of the first acts of the Soviet government was to change the width of the rail network from the standard track gauge $(1,435 \mathrm{~mm})$ to the broad Russian one $(1,520 \mathrm{~mm})$. These changes were implemented in all the territories annexed to the Soviet Union within the framework of Sovietisation measures. Particular attention was paid to control (and prevent) the connection between local people and residents of the neighbouring countries often with the same ethnic background. According to this goal, only a few crossing points were established and especially the number of checkpoints for international railway passengers was limited. Chop became one of five such checkpoints for international passenger trains crossing the entire western border of the Soviet Union.

\section{Transport factors}

The transport geographical location of Transcarpathia within Ukraine is very specific. It is mainly the outcome of the political geography of the region and

${ }^{2}$ Similar concessions were made in favor of Romania also on its border with Hungary, where the territory inhabited predominantly by Hungarians along which the railway line Oradea-Satu Mare was ceded to Romania, because of military strategic and economic considerations. 
the above-mentioned geopolitical events. The most important cargo and passengers line in the state's railway communication system of Ukraine has been the Bryansk-Kyiv-Chop direction since the times of the former Soviet Union, originating from Moscow and connecting to the Central European railway network (Geographiya... 1969, p. 32). This line has always had a great international significance therefore it was electrified in the Soviet era (Afanasyev, N.P. and Sergushev, Yu.V. 1973, p. 142; Geographiya... 1969, p. 36). At the beginning of the $1980^{\mathrm{s}}$ another main international COMECON railway line (Kryvyi Rih-Fastiv-L'viv-Batiovo/Záhony-Budapest) also passed through the territory of the region (BIRYukov, V. 1979). As we can see, the two railway lines from Moscow and Kryvyi Rih converged in the western regions of Ukraine, where the railway stations of the region played an important role in the foreign trade transportation operations of the former USSR in the direction of the European parts of COMECON.

Analysing the configuration of the Transcarpathian railway network we should bear in mind that it consists of two unequal parts: broad gauge railroads and standard gauge ones. The former had been built on the basis of military strategic interests, and the latter were the results of private initiatives, generated mainly by the timber export from the Carpathians. This has led to the genesis of a highly unique railway network in Transcarpathia, most of which had been built by the Austro Hungarian Monarchy basically to ensure rapid movement of troops from the Empire to Eastern Galicia. The existing standard gauge lines in Transcarpathia were only a supplement of the transversal railway line of Chop-Khust-Rakhiv. They were built later and they had only local importance. Since World War II the length of railway lines in the region has significantly decreased. Especially standard gauge railway lines ceased to operate (many of them during the years of Ukraine's independence), largely due to natural disasters.

After World War II the increasing international traffic between the Soviet Union and the communist countries of East Central Europe required electrification of existing lines and construction of the second track. Due to military and strategic considerations modernisation was focused on the Lviv-Stryi-Chop line during the Soviet period. This railway line connects Transcarpathia and L'viv regions, and has outmost geopolitical importance. There is also the one-way Beskydskyi tunnel, which makes control over the line significantly easier. This was exactly the reason why that section of the Lviv Railway (Mukachevo-Lavochne), which includes the tunnel, was firstly electrified (1956), and it was also the first section which obtained double-track infrastructure (1975). These improvements increased the transfer capacity of the line significantly.

As part of railway modernisation the second main Soviet export route (Lviv-Sambir-Chop) was equipped with Diesel trains in 1960. Thus, 


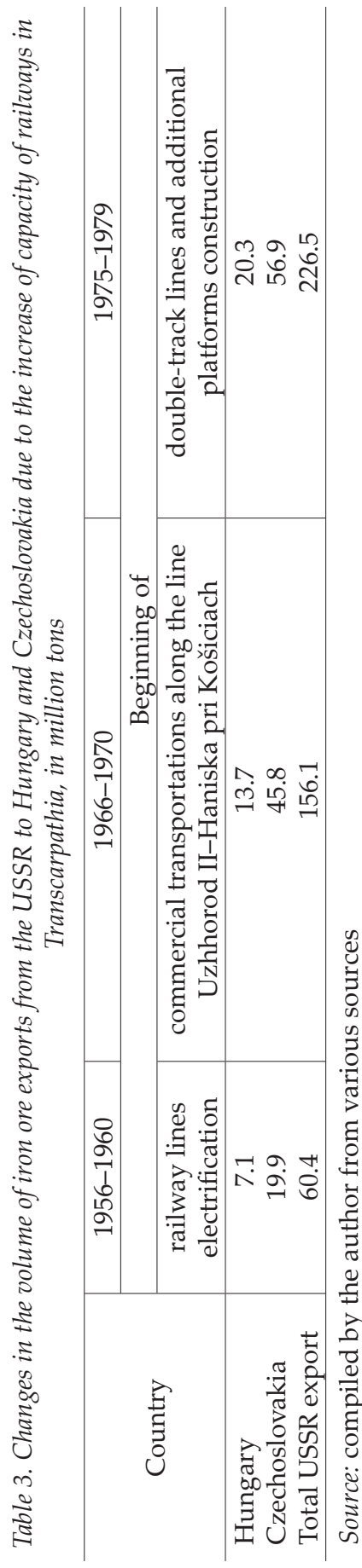

the two main railway lines passing through the Carpathians were among the firsts in Ukraine that were equipped with modern technology in order to meet the growing requirements set by Soviet export freight transportation. Thus, the capacity of foreign trade shipments, predominantly of bulk cargo exports from the USSR, grew steadily (Table 3).

For example in 1969 more than 11 million tons of cargo were delivered to Záhony (Hungary) from the Chop junction, which made around $30 \%$ of all deliveries of goods from Transcarpathia and $32.2 \%$ of all Hungary's international cargo (Afanasyev, N.P. and Sergushev, Yu.V. 1973, p. 150).

Within the framework of the Soviet modernisation programme $153 \mathrm{~km}$ of additional lines and inserts of binary railways were built by the USSR on the route of L'viv-Chop as well as StryiInternational boundary-Uzhgorod II-Batiovo in the 1970s. Also, new crossing points across the state border (Batiovo and Uzhgorod-II) were constructed, whereas existing railway border crossing stations were renovated and technically upgraded (Photo 2).

This provided the basis mainly for the growth of rail-freight traffic of bulk loads, transported from the USSR through Transcarpathia to Hungary and Czechoslovakia. The export of iron ore by railway lines increased especially dramatically during Soviet times. It was also connected with the opening of new metallurgical works built with the assistance of the USSR and with cooperation of the Ukrainian SSR in Hungary - Dunaújuáros (1954), in Poland - Kraków-Nowa Huta (1952) and Czechoslovakia - the Eastern Slovakian metallurgical plant near Košice (1966). They were designed to use imported iron ore from Krivyi Rih (Ukraine). The biggest volume of iron ore export from the USSR toward Czechoslovakia was reached in 1976 and in the case of Hungary in 1978. 


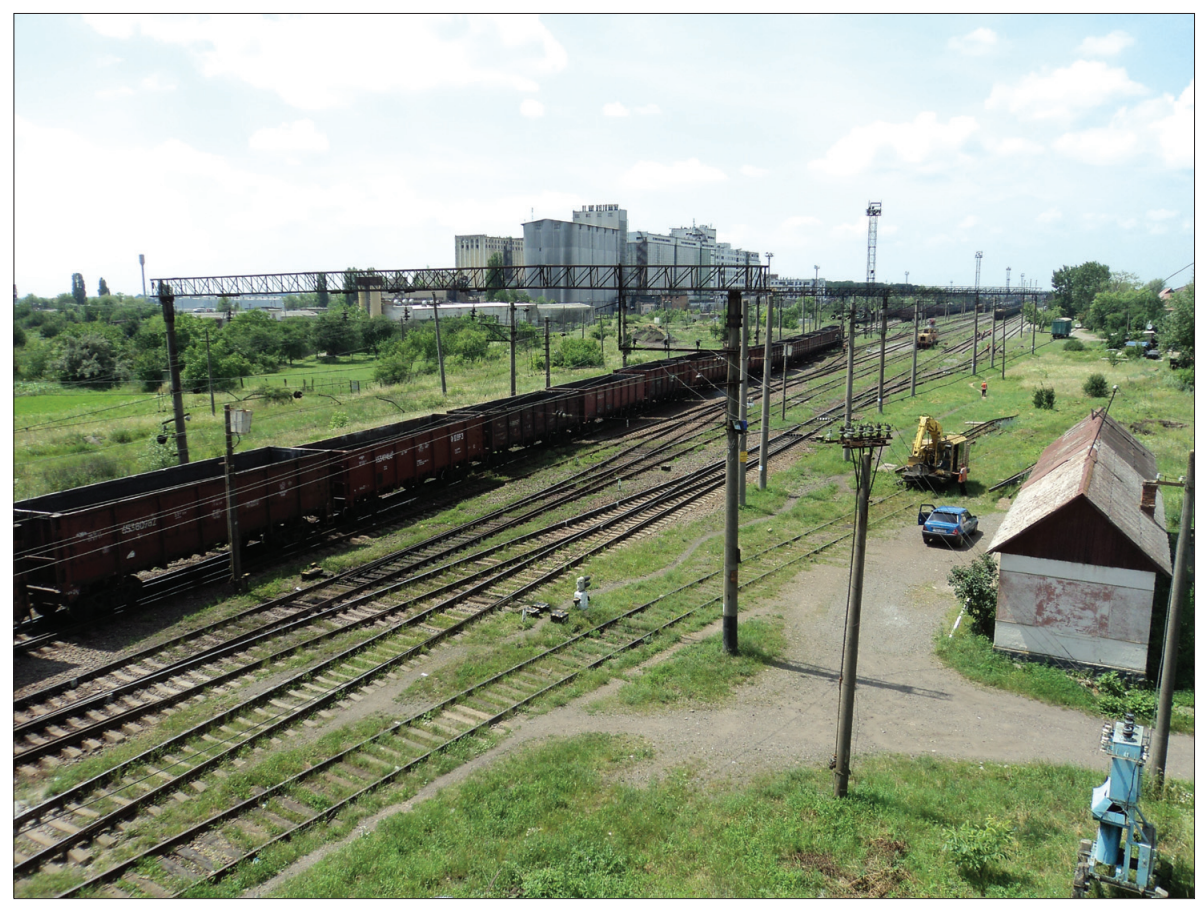

Photo 2. The modernised freight station of Uzhgorod II

\section{The changing role of international railway communication in Transcarpathia after Ukraine's independence}

There were several innovations regarding international railway communication that has affected Transcarpathia after Ukraine became independent in 1991. To attract new transit cargo new and renovated machinery for cargo transfer and car bogies rearrangement was introduced at the border station of Chop which allowed a growth in international traffic (Mukminova, T.A. et al. 2002).

The introduction of international container and controller trains became also an important step forward in railway services. The first of them was Ukraine-Express between Kyiv and Hamburg, which started its operation in 1996 (Mukminova, T.A. et al. 2002, p. 69). Today, four such international freight trains operate on a permanent basis one of them (Csardas) is passing the entire territory of Ukraine and interconnecting Budapest and Moscow via Transcarpathia.

An important factor contributing to the increase of transit and export rail transportation was the accession of Ukraine to the Convention Concerning International Carriage by Rail (2003). This has greatly affected the speed of 
movement in international rail traffic. For example, after the Chop-Dyakovo section was modernised in 2002-2004 with the cost of ca. 8.9 million EUR and customs control for international transit trains coming through Ukraine to neighbouring countries were simplified, the relevant cargo transportation increased drastically.

The development of railway infrastructure has also great potentials. For example, the longest $(1,746 \mathrm{~m})$ single track Beskydskyi tunnel on the double-track section of Stryi-Batiovo of the $5^{\text {th }}$ European transport corridor can only be passed by up to 24 pairs of freight trains and 23 passenger trains per day, whereas the capacities of the line would allow the passage of more than 100 train pairs a day (KIRPA, G.M. 2004). The construction of the second tunnel was started in 2012, and this is the biggest railway project in the country since Ukraine gained independence (Photo 3). The estimated cost of construction is around 102.7 million EUR (Budivnytstvo... 2012).

After 1991 the role of international railway communication via Transcarpathia has tremendously increased. This is mainly due to the fact that Ukraine carries out its exports to Hungary, Romania and Slovakia mainly by railways. According to our calculations, in 2011 the share of railway transport

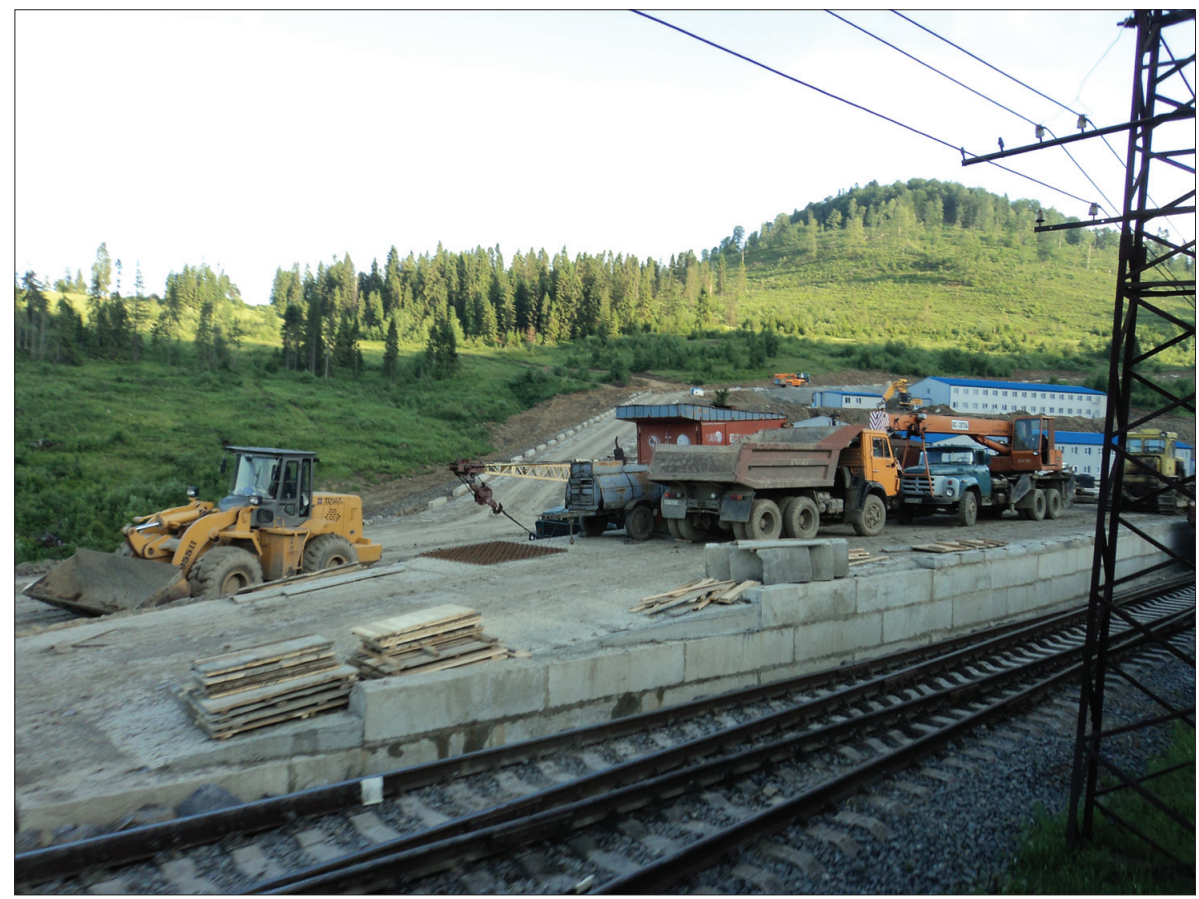

Photo 3. Construction of the new Beskydskyi tunnel 


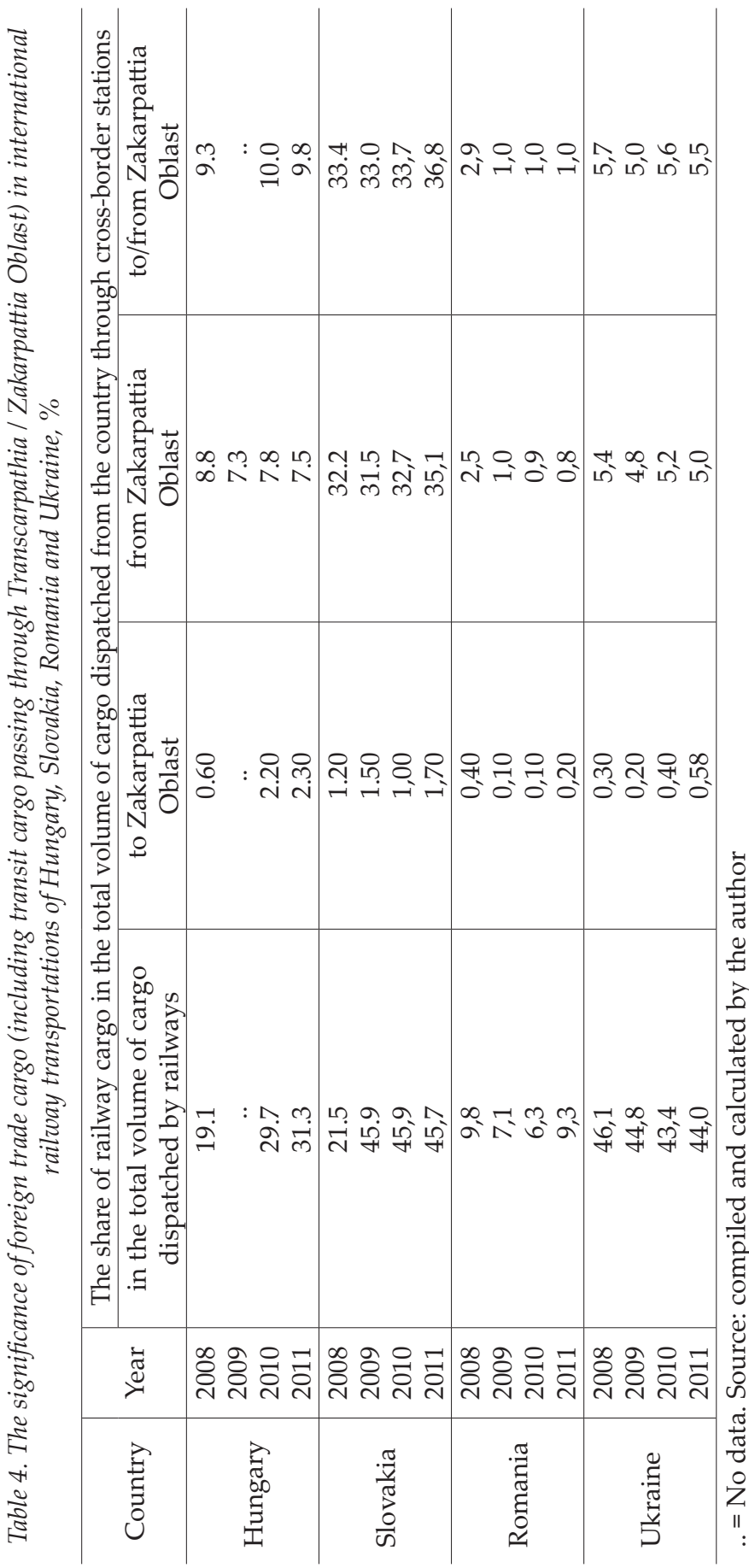

reached $94.5 \%$ of all export cargo from Ukraine to Slovakia, $69.7 \%$ to Hungary, and $54.3 \%$ to Romania (Transport 2012, p. 84), which shows the key role of Transcarpathia's railway network in the foreign trade of independent Ukraine. However, great imbalances in the volumes of international shipment flows can be observed that are inherited from the Soviet era (Table 4).

These imbalances are caused by shipments of iron ore and coal mainly, which are supplied to big metallurgic plants and thermal power stations in the neighbouring countries, constructed with the assistance of the USSR.

In the following we shall analyse the role of commercial freight railway transportations between Ukraine and the neighbouring Central European countries in accordance with their share in the total volume 


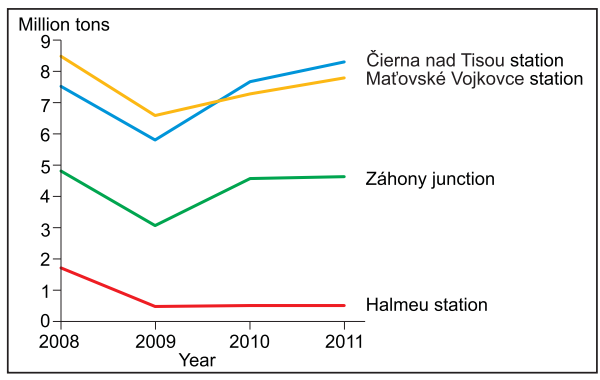

Fig. 2. Cargo turnover at cross-border freight stations connecting Transcarpathia with the neighbouring countries

of cargo transported by the railways in these countries. Special attention will be paid to the role of cross-border freight stations, enabling international cargo transportation from Transcarpathia (Figure 2).

\section{Slovakia}

The cargo arriving through the freight stations in Transcarpathia plays a key role in the volume of all commercial freight traffic of Slovak railways. In 2012 shipments from Ukraine occupied the leading position in the total commercial freight traffic of Slovak national cargo railway company ZSSK Cargo Slovakia - 15.6 million tons or $42.5 \%$ of the total commercial freight traffic in the country. Transit shipments from Russia constitute a significant part of the delivered cargo. The major volume of shipments is carried out by broad gauge lines within Slovakia through East Slovak Transshipment Yards, consisting of the freight stations at Mat'ovce and Čierna nad Tisou, having direct connections with the railway network of Transcarpathia. It should also be noted that the cargo turnover of these freight stations showed increasing dynamism during the last three years, which is the evidence of the recovery of Slovakia from the economic crisis (Figure 2).

At present the principal aim of the ZSSK Cargo Slovakia is to increase transit shipments along the $5^{\text {th }}$ and $6^{\text {th }}$ European transport corridor due to transit deliveries mainly from Russia to Austria and the Czech Republic. In 2008 Russian Railways (RZD) leased the end point of Slovakian broad gauge line, freight station Dobrá (10 km from the border with Ukraine) for 15 years with the aim of readjusting containers to broad gauge car bogies in an attempt to increase transport shipments along the $5^{\text {th }}$ European transport corridor, which also runs through the territories of Ukraine and Russia.

Slovakia's efforts make the country one of the most important players in transit transportation of commercial cargo from Russia through the Ukrainian railway network. In 2012 Slovakia occupied the leading position among all European countries regarding the volume of Russian transit cargo passing through Ukraine (3.42 million tons). The policy of Slovakia focuses mainly on container transit. Containers are being readjusted to broad gauge car bogies at the freight station Dobrá for their further departure into the Ukrainian broad gauge railway network through the freight station Chop. Thus, e.g., out of six transit container trains, which ran in 2012/2013 from Russia through the territory of Ukraine used the above mentioned route. 
Ukrainian railways are very important transit routes for the Russian Railways. In particular, the role of the broad-gauge railway corridor MoscowKyiv-Bratislava-Vienna through Transcarpathia is outstanding. It is expected that by 2025 the volume of transit traffic along this line will reach 35 million tons (Shyroka... 2008).

\section{Hungary}

Hungary is less dependent on cargo delivery from Ukraine than Slovakia. Hungarian stations Záhony and Eperjeske form together the Záhony junction which is the main rival of Slovakian border freight stations in freight traffic from Ukraine as well as in cargo transit from Russia. The infrastructure of this junction was developed during the COMECON era. Earlier the Hungarian direction enjoyed priority in the international freight traffic of the USSR, therefore, the binary Chop-Záhony international rail junction was heavily developed at a European scale. Natural conditions played an important role in the development of the Záhony rail junction. Smooth relief of the Great Hungarian Plain to which the south western part of Transcarpathia belongs, makes railway transportation through Hungary less expensive than through the hilly terrain of Slovakia.

The higher density and better connectivity of the Hungarian railway network with the neighbouring countries (as opposed to Slovakia and Romania) also facilitated the use of the Hungarian railways for Soviet foreign trade with Central Europe. Today the advantages of the favourable geographical location of Hungary are effectively used for cargo transportation not only between East and West, but also along the North-South route. Accordingly, most European transport corridors in Central Europe run through the territory of Hungary.

Contemporary international railway traffic through Transcarpathia to Hungary is carried out at the Záhony junction, which has transfer capacity of 18 million tons. However, at present only small part of the capacity is used. E.g. in 2011 cargo turnover reached only 4.65 million tons, whereas in 1969 it was over 11 million tons (Afanasyev, N.P. and Sergushev, Yu.V. 1973, p. 150).

The Russian Railways rejected the old Soviet policy in the field of transport logistics with the Central European countries, having transferred the majority of its shipments to the Slovakian railways. This caused substantial reduction in the volumes of cargo transit by the RZD through the territory of Transcarpathia to Hungary. A series of projects have been initiated with the aim of preventing further decline of cargo turnover at Záhony freight station, e.g., in 2011 the idea of a new railway corridor Khorgos-Záhony between China and Hungary running through the territory of Kazakhstan, Russia 
and Ukraine was put forward. Also activities of bringing new impetus to the transportation along the $6^{\text {th }}$ European transport corridor which ends in the territory of Hungary in Záhony, was started. Moreover, large-scale reconstructions have been carried out in Záhony in order to attract new cargo flows to the junction, particularly the broad gauge track, running from Chop junction, has been reconstructed.

At present the principal volume of freight traffic is carried out between the freight stations of Batiovo (Ukraine) and Eperjeske (Hungary), where big transfer plants for bulk loads operate. In 20113.13 million tons of cargo was dispatched from Batiovo to Eperjeske, and 1.1 million tons passed the opposite direction. We should note that among the freight stations situated on the western border of Ukraine, Batiovo takes the second place after the station Izov (Volyn Oblast) according to the volume of international railway freight traffic.

The shipments of iron ore from Ukraine still constitute the bulk of international freight traffic between the freight stations Batiovo and Eperjeske, as it was in the Soviet time. Thus, e.g., in 2010 iron ore accounted for more than $2 / 5$ of the total cargo turn-over at Záhony junction. In addition coal from Donbas also plays an important role. Most of these shipments are delivered to the biggest metallurgic plant in Hungary ISD Dunaferr, which belongs to the Ukrainian company ISD (Industrial Union of Donbas). The fluctuations in the import of iron ore to Hungary directly influence the transfer turnover of the Záhony rail junction. Although on a limited scale, there is occasionally international transportation of cargo also along the standard gauge railway line between the freight stations Záhony-Chop-Cierna nad Tisou. In 2011355 thousand tons of cargo was delivered in the given direction from Hungary to Slovakia.

\section{Romania}

The freight stations Dilove and Teresva, situated near the Khust-Rakhiv railway line (passing through the territory of Romania), were not used for international commercial railway freight traffic in the period of 2008-2011. Therefore cargo turn-over between the freight stations of Dyakovo (Ukraine) and Halmeu (Romania) was the smallest among the investigated sections. From the viewpoint of Romanian State Railways the international cargo turnover with Ukraine and transit freight traffic from Russia is minimal. This can be explained by the fact that the volume of foreign trade railway shipments between Romania and Ukraine is 2.3 times less than the corresponding index with Slovakia (2011). As Figure 2 shows, cargo turnover of the freight station Halmeu remains the lowest among all the investigated freight stations at the borders of Transcarpathia.

There is one feature, however, strongly characteristic for the international railway freight traffic between Dyakovo (Ukraine) and Halmeu (Romania), 
which is common for all cargo transportations between Ukraine and the Central European countries: the predominance of export shipments over the imports. Thus, e.g., in 2011 only 21 thousand tons of cargo was dispatched from the freight station Halmeu to the freight station Dyakovo, whereas in the opposite direction 502.73 thousand tons was transported. The persisting economic crisis in Romania does not allow for the restoration of the pre-crisis volume of shipments. In 2008 the volume of cargo dispatched from the freight station Dyakovo was 1,647.1 thousand tons.

The absence of transit shipments by standard gauge lines through Transcarpathia affects the exploitation of existing possibilities in international transport relations between Ukraine and Romania. This is partly the reason why the given railway line and its extensions on the territories of Slovakia and Romania was not included in any European transport corridor.

Our analysis on the international commercial freight traffic between Transcarpathia and the neighbouring countries showed distinct geographical features:

1. The bulk of foreign trade between Ukraine and the Central European countries is carried out by railway.

2. Shipments from Ukraine constitute the major part of the cargo turnover of the freight stations on the border of Ukraine, and the main part of transit shipments is provided by cargo from Russia.

3. Cargo dispatched from Ukraine strongly exceeds cargo dispatched from Hungary, Romania and Slovakia towards Ukraine.

4. Iron ore is the key commodity in the shipments of cargo from Ukraine, which is delivered to the metallurgic plants built in the COMECON era with the active assistance of USSR using iron ore from Kryvyi Rih and coal from Donbas.

5. Any changes in the volume of international freight traffic in Transcarpathia are directly linked with the development of metallurgy in the neighbouring Central European countries.

6. The existing transfer and trans-shipping capacities are sufficient for further growth of the volumes of commercial freight traffic at the freight stations of Transcarpathia.

\section{Conclusions}

The manifestation of historical inertia, both in the fields of directions of international rail services and in the use of existing station and track facilities in Transcarpathia can be clearly demonstrated. Many of the existing problems in the development of rail transport in Transcarpathia are related to physical geographical aspects. The natural conditions of the region are dominated 
by a mixture of mountainous and lowland areas. The existence of numerous viaducts, tunnels and bridges, as well as a significant slope profile of the road constitute an important problem. After independence of Ukraine the reconstruction and modernisation of the track facilities in the low-lying parts of Transcarpathia was started with the aim of increasing the transit capacity with Slovakia and Romania. The decision to reconstruct the Beskydskyi tunnel in the mountainous part was made only recently. This will, however, significantly increase the capacity of the $5^{\text {th }}$ European transport corridor.

The shifts in the geopolitical situation in East Central Europe after the collapse of the communist block and the USSR provided good opportunities to increase the transit potential of Transcarpathia. The emergence of new countries changed the role of the region in the railway traffic of the Central European states. Ukraine's accession to the Convention concerning International Carriage by Rail (2003) facilitated the further development and increased use of the existing lines especially for the purpose of cargo transportation.

The present railway network of Transcarpathia has a number of railway sections, which are of little or no use in cargo transportation. The network of the standard gauge lines was reduced most drastically in the post-war period, and at the same time the volume of operation of the number of lines rose significantly due to the growth of international cargo traffic. This led to the development of a number of railway freight stations in Transcarpathia. A striking example of this change is the construction of a new railway station (Uzhhorod-II), the modernisation and expansion of the Chop rail centre, the construction of the second track on the Lviv-Stryi-Batiovo-Chop railway line, the construction of the standard gauge railroad Uzhhorod-II (Ukraine)-Haniska pri Košiciach (Slovakia). Yet, there are several opportunities for the increase of transit passenger and cargo traffic after a dramatic decline in the 1990s.

Considering the geographical location of Transcarpathia and its railways, it seems to be possible to return to the pre-crisis traffic level through the attraction of additional cargo and passengers in international transit traffic. However, for this purpose opportunities provided by international transport agreements regarding the European transport corridors, as well as bilateral agreements, or the development of transport infrastructure in the Carpathians EU region should be fully utilised.

\section{REFERENCES}

Afanasiev, N.P. and Sergushev, Yu.V. 1973. Transport Vengerskoy Narodnoy Respubliki (Transport of the People's Republic of Hungary). Proceedings of the Institute of Complex Transport Problems of the USSR State Planning Committee 37. 128-178.

Alenichev, S.P. 2004. Ukrzaliznytsya na kolee KOTIF (Ukrzaliznytsya on track COTIF). Railway Transport of Ukraine 4. 23-25. 
BIRYuKov, V. 1979. Sochetaya natsionalnye i integratsionnye usiliya (Combining national and integration efforts). Economic Cooperation COMECON Member Countries 5. 44-48.

Budivnitstvo dvokoliynogo Beskidskogo tunelyu u Carpatakh rozpochnetsya vzhe tsogo roku (Construction of the double-track tunnel Beskyd in Carpathians begin this year). 2012 http://www.uz.gov.ua/press_center/up_to_date_topic/310765/

Geographiya putey soobsheniya, 1969 (Geography of Transport, 1969), Moscow, Transport, $241 \mathrm{p}$.

KIRPA, G.M. 2004. Integratsiya zaliznichnogo transportu Ukrainy u yevropeyskyu transportnu systemu (Integration of Railway Transport of Ukraine into the European transport system). Dnipropetrovsk, Dnipropetrovsk National University of Railway Transport, $248 \mathrm{p}$.

Kocsis, K., Rudenko, L. and Schweitzer, F. 2008. Ukraine in Maps. Kyiv-Budapest, Institute of Geography, National Academy of Sciences of Ukraine - Geographical Research Institute, Hungarian Academy of Sciences, $147 \mathrm{p}$.

Muкminova, T.A., Zuвко, A.P. and Tкаснеnко, A.P. 2002. Na puti k stabilnomu razvitiyu ekonomiki zheleznodorozhnoy otrasli (On the way to the stable development of the economy of the railway industry). Railway Transport of Ukraine 6. 61-69.

Muкminova, T.A. 2004 MTK yak zasib ekonomichnoy integratsiy Ukrainy (ITC as a means of economic integration of Ukraine). Railway Transport of Ukraine 4. 19-23.

Natsionalnyy atlas Ukrainy (National Atlas of Ukraine), 2007. Kyiv, State Research and Production Enterprise Kartografiya, 440 p.

Ohlyad pavodkovoy diyalnosti 1998-2001 rokiv ta propozytsiy po zapobigannyu povenevikh situatsiy (Review flood of 1998-2001, and suggestions to prevent flood situations), 2001. http://www.ulrmc.org.ua/services/Zakarpattia/information_ua.html\#4.1

SAVCHUк, I.G. 2010a. Zagalni tendentsiï rozvitku eksportu poslug zaliznichnogo transportu v Ukraini (General trends in services exports Railway Transport in Ukraine). Journal of Social and Economic Geography 9. 96-98.

SAvchuK, I.G. 2010b. Peredumovi rozvitku mizhnarodnogo pasazhirskogo zaliznichnogo spoluchennya Ukrainy (Background of international passenger railway Ukraine). Scientific Journal of the National Pedagogical University named M.P. Drahomanov. Series 4. Geography and Modernity 24. 205-209.

SAvchuк, I.G. 2011. Transitnyy potentsial Ukrainy u mizhnarodnomu pasazhirskomu zaliznichnomu spoluchenni (Transit potential of Ukraine in the international passenger rail). Scientists note Taurian National University named V.I. Vernadsky 24. (2): Part 1. 280-284.

SAVCHUK, I.G. 2012a. International passenger railway communication in Ukraine. Geography, Environment, Sustainability 1. 18-29.

SAVсник, I.G. 2012b. Vpliv eksportnoï oriyentatsiï zaliznichnogo transportu Ukrainy na yogo rozvitok za roky nezalezhnosti (The influence of the export orientation Ukrain's railway transport on its development in the years of independence). Economy of Ukraine 7. 36-44.

Shyroka koliya protyahnetsya do tsentru Yevropy? (Broad gauge stretch to the centre of Europe?) 2008. http://www.uz.gov.ua/press_center/mass_media_about_ukrainian_railway/238404/

Soglasovannaya zheleznodorozhnaya transportnaya politics OSJD (Agreed OSJD rail transport policy), 2002. Warsaw, Organisation for Co-operation between Railways (OSJD), 59 p. 


\title{
Ukraine in Maps
}

\author{
Edited by: Kocsis, K., Rudenko, L. and Schweitzer, F.
}

\author{
Institute of Geography National Academy of Sciences of Ukraine \\ Geographical Research Institute Hungarian Academy of Sciences. \\ Kyiv-Budapest, 2008, 148 p.
}

Since the disintegration of the USSR, the Western world has shown an ever-growing interest in Ukraine, its people and its economy. As the second-largest country in Europe, Ukraine has a strategic geographical position at the crossroads between Europe and Asia. It is a key country for the transit of energy resources from Russia and Central Asia to the European Union, which is one reason why Ukraine has become a priority partner in the neighbourhood policy of the EU. Ukraine has pursued a path towards the democratic consolidation of statehood, which encompasses vigorous economic changes, the development of institutions and integration into European and global political and economic structures. In a complex and controversial world, Ukraine is building collaboration with other countries upon the principles of mutual understanding and trust, and is establishing initiatives aimed at the creation of a system that bestows international security.

This recognition has prompted the Institute of Geography of the National Academy of Sciences of Ukraine (Kyiv) and the Geographical Research Institute of the Hungarian Academy of Sciences (Budapest) to initiate cooperation, and the volume entitled "Ukraine in Maps" is the outcome of their joint effort. The intention of this publication is to make available the results of research conducted by Ukrainian and Hungarian geographers, to the English-speaking public. This atlas follows in the footsteps of previous publications from the Geographical Research Institute of the Hungarian Academy of Sciences.

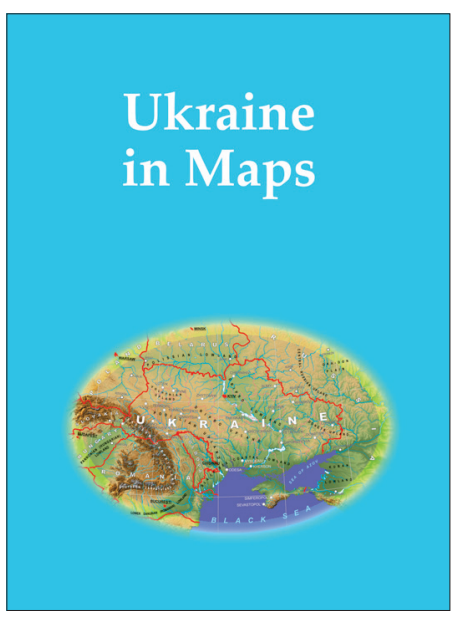
Similar to the work entitled South Eastern Europe in Maps (2005, 2007), it includes 64 maps, dozens of figures and tables accompanied by an explanatory text, written in a popular, scientific manner. The book is an attempt to outline the geographical setting and geopolitical context of Ukraine, as well as its history, natural environment, population, settlements and economy. The authors greatly hope that this joint venture will bring Ukraine closer to the reader and make this neighbouring country to the European Union more familiar, and consequently, more appealing.

Price: EUR 35.00

Order: Geographical Institute RCAES HAS Library

H-1112 Budapest, Budaörsi út 45.

E-mail: magyar.arpad@csfk.mta.hu 